\title{
PROFESORS KONSTANTİNS ČAKSTE. ZIEDOJUMS UZ TAUTAS BRĪVĪBAS ALTĀRA. PERSONĪBAS, KAS SAVIENO LAIKUS
}

\section{PROFESSOR KONSTANTĪNS ČAKSTE. SACRIFICE ON ALTAR OF NATION'S FREEDOM. PERSONALITIES BRIDGING TIMES}

\author{
Diāna Apse, Dr. iur. \\ Latvijas Universitātes Juridiskās fakultātes \\ Tiesību teorijas un vēstures zinātṇu katedras docente
}

\section{Summary}

The author examines the most relevant aspects of Konstantīns Čakste's life, personality, as well as his scientific and political contribution that facilitated continuous and symbolic legal succession of the only possible Latvian state. Over the course of his life, Konstantins Čakste persistently defended the principles of democracy. His distinction was rooted in family - his father was the first President of Latvia Jānis Čakste, who nurtured the idea of the basic norm from the pre-democracy period. Konstantins Čakste is a symbol that unites our hearts and the Latvian state. The author draws parallels in the personalities who laid the legal foundations for the restoration of the Latvian state and those who with their immense belief in the Latvian state and Latvian nation gave wing to the people anew. The personalities who bridge times - the "the third front's" attempt to restore the Latvian state at the end of World War II (Konstantins Čakste) and the third awakening with the Declaration "On the Restoration of Independence of the Republic of Latvia" of 1990 (Romāns Apsītis).

Atslēgvārdi: Satversme, neatkarība, atmoda, vērtības, nepārtrauktība

Keywords: Satversme, independence, awakening, values, continuity

Laimīgas ir tautas, kam ir cilvēki stipri garā, iekšèjā spēkā un gudrībā, dvēseles brīvībā un dzīves izdarībā. Tie ir, kas uzvar dzīvi,

likteni un nāvi. Nāvi uzvar tas, kas no tās nebaidās un droši lìdz galam nostaigā savas dzīves gaitas, piepildìdams savu dzīves sūtību.

Anastasija Čakste 


\section{Ievads}

Viṇš izauga sevī dižens no savas dzimtas, no tēva Jāṇa Čakstes, kurš izauklēja pamatnormas $^{1}$ ideju no pirmsdemokrātijas laika. Viņš un viṇa dzimtas locekḷi spēja mācīties un izdarīt secinājumus no vācu kundzības gadiem, no 1905. gada, ulmaņlaikiem. Viṇi izveidojās par nacionālu eliti, audzinot līdzcilvēkus demokrātijas vērtībās. Konstantīns Jēkabs Margérs Čakste - simbols, kas savieno mūsu sirdis un Latvijas valsti.

Neatkarīga, brīva, tiesiska un demokrātiska Latvija - ideja, par kuru vērts pat mirt. Tik vērtīga ir šì ideja! ${ }^{2}$

Atsevišķiem ārvalstu pētniekiem radies iespaids, ka Latvijā vēsturisko notikumu atcere ir vienīgi personisks process, kurā ārpasaule nav aicināta vai pat liegts tai piedalîties. Latvijā atcere izpaužas divējādi. Ir atceres pasākumi, kurus latvieši atzīmē kopā ar tautiešiem, un ir atcere, kurā tie dalās ar ienācējiem, kuri kaut kad vēlāk var radīt apdraudējumu. Šķiet, piesardzība un varbūt arī noklusēšana ir neatņemamas atceres procesa sastāvdalıas. ${ }^{3}$

Piemiņas vietas, cilvēku atmiņas, atstātais publikāciju, tiesu prakses mantojums, apzinot izcilāko Latvijas juristu likteņus, atklāj demokrātiskai un tiesiskai Latvijai veltītus mūžus. Ko nozīmē pienācīgi pieminēt un atcerēties spilgtākās juristu personības un viṇu paveiktos darbus? Tas nozīmē jurista pienākumu - pētìt un izzināt izcilu juristu nopelnus demokrātijas pamatu izveidē un nostiprināšanā, un darìt to nepārtraukti! Jo viņi bija, ir un būs Latvijas lepnums, patrioti, demokrāti un morālie orientieri.

Baltijas valstu faktiskā neatkarība tika atjaunota, pamatojoties uz valstiskās nepārtrauktības doktrīnu. Baltijas valstis konstitucionāli atzina sevi par tām pašām valstīm, kuru neatkarību prettiesiski bija pārtraukusi PSRS īstenotā okupācija un inkorporācija, un izvirzìja attiecīgu atzī̌anas prasību starptautiskajai kopienai. Starptautiskā kopiena šādu Baltijas valstu pašnovērtējumu ir atzinusi. ${ }^{4}$

Okupācijas apstākḷos juridiski neatkarīga Latvijas valsts turpināja pastāvēt, lai arī tās rīcíbspēja faktiski nebija īstenojama. Taču šajos ierobežotajos apstākḷos tieši personības turpināja valsts tiesībspēju. Iepazīstoties ar viṇu dzīves gājumu, var secināt, ka, neskatoties uz okupācijas varas radītajiem šķēeršliem, viṇi drosmīgi turpināja aizsargāt un isstenot pamatnormu, nodrošinot valsts juridisko turpinātỉbu, saistību un tiesību juridisko nepārtrauktību. ${ }^{5}$ İpaši minami Konstantīns un Mintauts Čakstes, kuru personības un darbỉba ietekmēja Latvijas neatkarības

1 Pamatnorma kā ațaujoša un pilnvarojoša tiesiskās kārtības vīzija ietver sevī spēku (Macht), gribu, kurā iekḷaujam tiesības (Recht), ko nosaka pieredze. Apse D. Pamatnormas īstenošanas uzturētāji: zināmie un nezināmie. Grām.: Centrālās un Austrumeiropas juridiskās tradīcijas un juridiskās identitātes jautājumi. Latvijas Universitātes 76. starptautiskās zinātniskās konferences rakstu krājums. Rīga: LU Akadēmiskais apgāds, 2018, 142.-150. lpp.

2 Pamatnorma ir tiesību sistēmas virsotne, kas nosaka visu normu spēkā esamību. Pamatnorma ir hipotētisks pieṇēmums par regulējumu, kas nosaka pirmās konstitūcijas vai jaunas konstitūcijas pieņemšanas kārtību gadījumā, kad noticis valsts iekārtas revolucionārs lūzums. Kelsen H. Introduction to the problem of Legal Theory. A Translation of the First Edition of the Reine Rechtslehre or Pure Theory of Law. Oxford: Clarendon Press, 2002, p. 59.

3 Hants V. Otrā pasaules kara beigas Kurzemes frontē. Asinis mežā. Rīga: Latvijas Mediji, 2018, 255. lpp.

4 Pleps J. Baltijas valstu valstiskā nepārtrauktība. Grām.: Nepārtrauktības doktrīna Latvijas vēstures kontekstā. Autoru kolektīvs prof. T. Jundža zinātniskā vadībā. Rīga: LZA Baltijas stratēǵisko pētijumu centrs, 2017, 75. lpp.

5 Plašāk sk.: Apse D. 2018, 142.-150. lpp. 
idejas. Šīs idejas līdzsapṇoja viṇu vecāki: māte Justīne Čakste - Piebalgas puses sabiedriskā darbinieka Fridriha Vesera meita (F. Veseris bija viens no Rīgas Latviešu biedrības dibinātājiem) un tēvs Jānis Čakste - pirmais Latvijas Valsts prezidents, advokāts, aktīvs sabiedriskais darbinieks. ${ }^{6}$ Viņu bērnu personības ietekmēja arī harmonija un draudzība, kas valdīja Čakstu gimenē. ${ }^{7}$

Viṇi bija no tiem pilsoniskās Latvijas politiķiem, kas visekstremālākajā situācijā izturēja pārbaudijumu un palika uzticami demokrātijai un Satversmei. ${ }^{8}$

Šì raksta mērksis ir aplūkot un analizēt personības nozīmi mūsu valsts attīstības svarīgākajos posmos, īpaši svešas varas klātbūtnes apstākḷlos valstiskās nepārtrauktības doktrīnas kontekstā.

\section{Konstantīns Jēkabs Marğers Čakste: dzīves gājums}

Konstantīns Čakste dzimis 1901. gada 26. jūlijā Bulduros kā sestais bērns gimenē. Tēvs Jānis Čakste, zvērināts advokāts, vēlāk - Latvijas Valsts prezidents. Māte Justīne Čakste. Konstantīnam Čakstem bija paraugs - vecākais brālis Mintauts Čakste. Četri juristi vienā gimenē! Čakstes tēvs ar saviem dēliem pārsprieda tieslietu jautājumus. Jānis Čakste mēdza atgādināt trīs baušlıs, kas būtu jāatceras arī mūsdienās: pirmkārt, mēs ne brīdi nedrīkstam aizmirst, ka lielvaras īsteno vienīgi savu interešu politiku, otrkārt, mūsu mazajām tautām arvien jācenšas izvairīties no bīstama šovinisma, un visbeidzot - Baltijas tautām jādzìvo draudzībā. ${ }^{9}$

Bērnībā Konstantīns pats sevi saucis par Tuntānu. Ģimenes locekḷi viṇu tā godāja arī tad, kad viņš bija precējies un kḷuvis par profesoru. ${ }^{10}$ Tuntāna personības iezīmes bija zinātkāre, radošums, dzīvesprieks, pienākums, mīlestība, gimeniskums. ${ }^{11}$

Skolas gaitas Konstantīns Čakste uzsāka 1909. gadā Jelgavas ǵimnāzijā un 1915. gadā turpināja evakuētajā L. Bērziṇa un F. Šmithena Dubultu g̛imnāzijā Tērbatā, bet no 1917. gada - Kazaṇas 3. gimnāzijā. Pēc atgriešanās Latvijā Konstantīns Čakste 1919. gadā iestājās Rīgas pilsētas 2. vidusskolā, ko pabeidza 1920. gadā. Tajā pašā gadā viṇš uzsāka tieslietu studijas Latvijas Universitātes Tautsaimniecības un tiesību zinātṇu fakultātes Tiesību zinātṇu nodaḷā. Latvijas Universitāti viņš beidza 1925. gadā. Pēc tam K. Čakste papildināja zināšanas Parīzes Universitātes Juridiskajā fakultātē (1932. gadā) un Briselē (1936./1937. gadā). 1928. gadā viṇš tika ievēēēts par Latvijas Universitātes jaunāko asistentu. Konstantīns Čakste darbojās pie ievērojamā profesora Dr. Vasilija Sinaiska kā viṇa asistents. 1931. gadā

${ }^{6}$ No muzeja Jāṇa Čakstes dzimtas mājas muzeja “Auči” vadītājas I. Freimanes stāstījuma muzeja apmeklējuma laikā 10.06.2015. Personiskā arhīva materiāli.

7 Vecāku viesmīlība un aktīvā sabiedriskā darbība, pašaizliedzīgs darbs biedrībās, komitejās, labdarības organizācijās, izpalīdzības un labdarības gaisotne it visā darītajā. Stipri, stalti un strādīgi. Viņi veidoja savu dzīves bagāžu, stāvot pie mūsu valsts šūpuḷa un vēlākos vēstures posmos. Apse D. 2018, 142.-150. lpp.

${ }^{8}$ Stradiņš J. Jānis Čakste un demokrātijas ideju iedibināšana Latvijā. Grām.: Jānis Čakste. Taisnība vienmēr uzvarēs. Atziṇas. Runas. Dokumenti. Raksti. Vēstules. 2. papildinātais un pilnveidots izdevums. Riga: Jumava, 2009, 11. lpp.

9 Auziņš A. Konstantīns Čakste. Rīga: Jumava, 2004, 17. lpp.

10 Ibid., 8. lpp.

11 Sākot no pārbaudījuma sava tēva bišu dravā: beidzot pirmo klasi, viṇš nolēma izzināt, vai pie bitēm var doties arī sporta biksēs un vingrot skrejas priekšā. Ibid., 9. lpp. 
pēc habilitācijas darba "Nomaksas pirkums Latvijā un ārzemēs" aizstāvēšanas Čakste kḷuva par Latvijas Universitātes privātdocentu Civiltiesību katedrā, bet 1934. gadā - par docentu. Konstantīns Čakste strādāja pie viena no ievērojamākiem franču juristiem - profesora Dr. H. Kapitāna. Kopš 1935. gada viņš bija arī docents tirdzniecības tiesībās. 1937. gadā viņš kḷuva par vecāko docentu (1938. gadā šo amata nosaukumu mainīja uz ārkārtējo profesoru) un lasīja tirdzniecības un civiltiesību kursu tautsaimniekiem. ${ }^{12}$

K. Čakste ar mīlestību un maigumu loloja savu ǵimeni, februārī dāvāja ziedošus ceriṇus sievai Anastasijai, slavēja viṇas garšīgās maltītes, vannoja savas meitiṇas, mācīja tām dejot, centās visādi iepriecināt. Divpadsmit skaistākie kopīgās laulības gadi. Pēc Konstantīna nāves Anastasija vēlreiz neapprecējās. ${ }^{13}$ Tādējādi viņš ielika stipru drošîbas pamatakmeni savu meitu apziṇā, nostiprinot viṇu pašvērtību, pārliecību par patiesām un godīgām attiecībām un palīdzību citiem kā cilvēka dzìves vērtību.

Kad izvirzījās jautājums, kurš varētu stāties neatkarības kustības priekšgalā, Alberts Kviesis, aizbildinoties ar savu vecumu, Jānim Lejiņam izstāstīja, kādam jābūt latviešu vadonim: izšķirīgā brīdī nepieciešams ātrums un enerǵija, bet vienmēr vajadzīga tālredzība, takts un populārs vārds. ${ }^{14}$ Tika nolemts, ka visprātīgāk par pretestības kustības vadītāju ievēlēt kādu no centra aprindām. ${ }^{15}$

Čakste veica arī pedagogiisko darbu. Viṇš lasīja lekcijas civiltiesībās Tautsaimniecības nodaḷas studentiem, bet no 1935. gada - lekcijas tirdzniecības un jūras tiesībās gan Tautsaimniecības nodạ̦as, gan Tiesību zinātṇu nodaļas studentiem. Pedagogisko darbu Konstantīns Čakste turpināja līdz 1944. gadam, kad tika arestēts.

1931. gadā viṇu ievēlēja par privātdocentu Civiltiesību katedrā, savukārt 1933. gadā - par vecāko docentu. Pēc tam, kad nosaukums "vecākais docents" 1938. gadā tika aizstāts ar nosaukumu "ārkārtējais profesors", Konstantīns Čakste kḷuva par ārkārtējo profesoru. 1935. gadā Konstantīns Čakste līdztekus uzsāka darbu Tirdzniecības tiesību katedrā vadītāja amatā, bet no 1938. gada līdz 1940. gadam veica arī fakultātes sekretāra pienākumus. 1933. gada 31. maijā viņš kḷuva par zvērināta advokāta Pētera Berǵa palīgu, bet 1936. gada 25. novembrī - par

12 Čakste bija arī Institut International d'Étude at de Documentation en matiére de Concurrence Commerciale loceklis. Viņš publicējās periodiskos izdevumos (galvenokārt žurnālos "Jurists” un "Tieslietu Ministrijas Vēstnesis”) par dzīvokḷu tiesībām, paju sabiedrībām un citām tēmām. Čakste redigéja Latvijas Universitātes akadēmiskās sabiedrisko zinātṇu veicināšanas biedrības Aequitas izdoto rakstu krājumu, bija biedrības valdes priekšsēdētāja biedrs. Laikā no 1938. līdz 1940. gadam ieṇēma žurnāla "Jurists" atbildīgā redaktora amatu. Kopš 1943. gada viņš bija arī Tautsaimniecības vārdnīcas redakcijas līdzstrādnieks. Pat pēc apcietinājuma, esot Rīgas centrālcietumā, vēl 1944. gadā viņš Tautsaimniecības vārdnīcas redakcijai sūtỉja rakstus par cilvēka tiesībām brīvi paust savu domu. Dunsdorfs E. Latvijai veltīts mūžs. Grām.: Andersons E., Siliņš L. u. c. Latvijas Centrālā Padome. Latvija un Rietumi. Latviešu nacionālā pretestības kustība. 1943-1945. Upsala, 2000, 390. lpp.

13 Auziňš A. 2004, 11.-13. lpp.

14 Ibid., 34. lpp.

15 Vācu okupācijas sākumā K. Čakste uzsāka sadarbību ar dažādām nacionālās pretestības grupām, kas iestājās par neatkarīgas un demokrātiskas Latvijas atjaunošanu, balstoties uz 1922. gada Satversmi. 1943. gada 13. augustā Latvijas Centrālās padomes dibināšanas sēdē viṇu ievēlēja par padomes priekšsēdētāju. K. Čakste darbojās LCP Juridiskajā komisijā un ir rediḡējis LCP programmu, kā arī piedalījies LCP nelegālā izdevuma "Jaunā Latvija” izdošanā. K. Čakste nodibināja un uzturēja sakarus ar Latvijas diplomātiskajiem pārstāvjiem ārvalstīs, kā arī ar igauṇu un lietuviešu nacionālās pretestības kustībām. Andersons E., Siliņš L. u. c. 2000, 49.-61. lpp. 
zvērinātu advokātu Rīgā. No 1932. gada līdz 1940. gadam Konstantīns Čakste bija sabiedriskā un tiesību žurnāla "Jurists" redakcijas kolēgijas loceklis.

Latvijas Universitātes Juridiskā fakultāte, kur gan Jānis Čakste, gan Konstantīns Čakste bija profesori, 2014. gadā abu juristu vārdā viṇu atcerei ir nosaukusi vienu no auditorijām, tā nesot viṇu pieminu mūžìbā.

K. Čakstes grāmata "Civiltiesības" izdota un izmantota arī mūsdienās, tādējādi nevar apšaubìt autora atziṇu nezūdošo vērtību. Grāmatas I daḷa sastāv no līdz šim nepublicētām Konstantīna Čakstes lekcijām, kas nolasītas Latvijas Universitātē laikā no 1937. gada 22. septembra līdz 1938. gada 4. maijam. Lekcijas veltītas galvenokārt Latvijas Civillikuma normu skaidrošanai. Savukārt grāmatas II daḷā ievietotas atsevišķiem civiltiesību jautājumiem veltītas Konstantīna Čakstes publikācijas. Ievērojamākās no tām - "Nama sadalīšana dzīvokḷos”, "Motorizēto satiksmes līdzekḷu īpašnieku atbildības problēma Latvijas un ārzemju civiltiesībās”, šo tēmu viņš pieteica abu okupāciju laikāa, ${ }^{16}$ un habilitācijas disertācija "Nomaksas pirkums Latvijā un ārzemēs".

1943. gada 13. augustā Konstantīnu Čaksti ievēlēja par Latvijas Centrālās padomes (turpmāk - LCP) priekšsēdētāju. Jāpiemin viņa darbība vēsturiski nozīmīgajā latviešu akadēmiskajā organizācijā “Austrums”, kuru 1883. gadā Maskavā dibinājis tēvs Jānis Čakste un kuras aktīvs biedrs bijis arī Konstantīns. ${ }^{17}$

Latvijas sabiedrībā pēdējos gados aktualizējusies interese par LCP darbību laikā no 1943. lìdz 1945. gadam, par profesoru Konstantīnu Čaksti un viṇa domubiedriem, par nacionālo pretošanos abām svešajām okupāciju varām.

LCP izveidoja ievērojami Latvijas Republikas politiķi, akadēmisko aprindu pārstāvji un militārpersonas. Organizācijā darbojās priekšsēdētājs Konstantīns Čakste, līdzās bijušais Saeimas priekšsēdētājs Pauls Kalniņš, ārlietu ministrs Fēlikss Cielēns, bīskaps Jāzeps Rancāns, generālis Verners Tepfers u. c. Galvenais veikums - memorands ar prasību par Latvijas valstiskuma atjaunošanu. Konstantīns Čakste ir bijis ietekmīga un ievērojama personība Latvijas un okupācijas varu laika Latvijas politiskajā un tiesiskajā vidē 20. gadsimta 30.-40. gados. K. Čakste ir darbojies gan brīvvalsts laikā valsts labā, gan miermīlīgi pretojies pret abu okupācijas varu nejēdzību.

1944. gada 29. aprīlī Gestapo (Geheime Staatspolizei) K. Čaksti arestēja. Tika arestēti arī citi LCP locekḷi. Apcietināto LCP darbinieku lietu Gestapo izmeklēja līdz 1944. gada 1. septembrim, kad Konstantīnu Čaksti, Bruno Kalninuu un Ludvigu Sēju no Rīgas centrālcietuma pārveda uz Salaspils koncentrācijas nometni. 10. septembrī no Salaspils ar tvaikoni Celebes viṇus pārveda uz Dancigu un ieslodzijja Štuthofas koncentrācijas nometnē. ${ }^{18}$ Konstantīns Čakste pēc aresta uzṇēmās visu atbildību par nacistiem tobrīd jau zināmo LCP darbību, lai glābtu citus organizācijas dalībniekus. Pat būdams ieslodzījumā, viṇš prata saglabāt savu optimismu un humoru, uzmundrinot citus arestētos, centās palīdzēt tiem, kas bija zaudējuši ticību nākotnei. ${ }^{19}$

16 Oponenti iebilda, ka Latvijā privāto motorizēto satiksmes līdzekḷu īpašnieku tikpat kā nav. Profesors drosmīgi atbildēja, ka atbildība jāprasa arī no neprivāto auto īpašniekiem par to, ka viṇi te pie mums sabrauc. Auziņš A. 2004, 28. lpp.

17 Tieši no austrumiešiem nāca rosīgākie LCP aktivitāšu veicēji. Arī pārējie Jāṇa Čakstes dēli - Ģedimins un Ringolds - bija šīs organizācijas biedri. Ibid., 20. lpp.

18 Čakste K. Civiltiesības. Lekcijas. Raksti. Rīga: Zvaigzne ABC, 2011, 9. lpp.

19 Ērglis Dz. Latvijas Centrālās padomes priekšsēdētājs Konstantīns Čakste. Grām.: Personība un demokrātija. Metodisks līdzeklis Latvijas vēsturē. Rīga: N.I.M.S., 2005, 55. lpp. 
Konstantīns Čakste mira 1945. gada 21. februārī ceḷā no Štuthofas nometnes uz Lauenburgas koncentrācijas nometni, apglabāts Polijas pilsētā Genšā (Gansas nometnes tuvumā). Apbedīšanai vajadzēja notikt līdz nometnes pārbaudes laikam plkst. 16.00. 22. februārī.

\section{Konstantīna Čakstes zinātniskā darbība un tiesiskie uzskati - vina iniciatīvas un darbïbas pamati LCP}

Konstantīna Čakstes zinātnisko darbību vislabāk raksturo viṇa publikāciju saraksts - Konstantīna Čakstes bibliogrāfija, kurā pirmais pētījums ir saistīts ar tiesiskās apziṇas problēmjautājumiem. ${ }^{20}$ Pēdējais izdevums: Čakste K. Cilviltiesības. Lekcijas. Raksti. Rīga: 2011. Publikāciju skaits, protams, ne vienmēr norāda uz zinātnieka kvalitāti. K. Čakstes zinātniskā devuma vērtējums salīdzinājumā ar mūsdienām nav bijis apjomīgs, to var skaidrot ar vēsturisko fonu un profesora aktīvo sabiedriski politisko darbību. Profesora K. Čakstes publikāciju analīze prasa īpašu padziḷinātu pētījumu, tomēr viens no viņa darbu zinātniskās kvalitātes raksturotājiem ir izmantotās zinātniski pētnieciskās metodes. K. Čakstes publikācijās dominē analītiskā, salīdzinošā un vēsturiskā izpētes metode, palīdzot pareizi analizèt, sintezèt un formulēt tiesības. Tas liecina par zinātnieka prasmi iekl̦aut paša pētnieka zinātniskās kvalitātes juridiskajā metodē un lasītāja patstāvīgās domāšanas attīstībā.

K. Čakstes uzskatus ietekmēja profesora V. Sinaiska ieskati par civiltiesisko sabiedrību - ievērot reālās dzives prasības, cenšoties tām dot nepieciešamo tiesisko ietērpu. Čakstes darbos manāms arī franču jurisprudences iespaids - noskaidrot attiecīgo institūtu aktuālākos pamatprincipus, piešķirot pētījumiem pārskatāmību, izvairoties no nevēlamas kazuistikas. K. Čakste savos darbos plaši piemēro salīdzinošo metodi, kas apliecina autora lielo erudīciju. Čakste aizstāvēja motorizēto satiksmes līdzekḷu īpašnieku un to vadītāju stingru atbildību par nodarìtajiem zaudējumiem kā līdzbraucējiem, tā arī pārējām personām ne tikai rupjas nolaidības, bet arī vieglas neuzmanības gadijumos. ${ }^{21}$

Kā politiķi Latvijas sabiedrība iepazina Konstantīnu Čaksti 1940. gada jūlijā, kad viņš kopā ar daudziem Latvijā pazīstamiem un populāriem cilvēkiem mègínāja pretoties padomju okupācijas varas sarīkotajām maskarādes “Tautas Saeimas” vēlēšanām, vienīgajam Maskavas noteicēju atḷautajam komunistu sarakstam cenšoties izvirzìt alternatīvu - tā saukto Demokrātisko bloku. Tas neizdevās, jo okupācijas vara šo sarakstu neatḷāva, un notika vēlēšanu farss, pēc kura Latvija

${ }^{20}$ Bibliogrāfija: Mūsu tiesiskās apziņas regress un viṇas pacelšana. Studentu anketes apskats. Jurists, 1928, Nr. 1; Tiesības uz vārdu un likums par vārdu un uzvārdu rakstību dokumentos. Jurists, 1928, Nr. 2; Nomaksas pirkums Latvijā un ārzemēs. Tieslietu Ministrijas Vēstnesis, 1931, Nr. 6/7, 8/9; Nama sadalǐšana dzīvokḷlos. Tieslietu Ministrijas Vēstnesis, 1933, Nr. 6/8, 9/10; Nejaušība un nepārvarama vara Latvijas civillikumos. Jurists, 1937, Nr. 71/72; 1937. g. 22. dec. Likums par akciju un paju sabiedrībām. Jurists, 1938, Nr. 85/86; 1937. g. 26. janv. Civīllikums. Izglītības Ministrijas Mēnešraksts, 1938, Nr. 2; Privāttiesības. Zinātne tēvzemei, 1938; Blanko vekseḷa ieguvēja tiesiskais stāvoklis. Jurists, 1939, Nr. 91/92; Motorizēto satiksmes līdzekḷu īpašnieka atbildības problēma Latvijas un ārzemju civiltiesībās. Latvijas Universitātes akadēmiskās sabiedrisko zinātṇu biedrības Aequitas rakstu krājums. II sēj. Akad. stud. vienības “Austrums” archīvs. Stokholma, 1939; Šulcs L. Profesora Konstantīna Čakstes zinātniskā darbība. Grām.: Andersons E., Siliņš L. u. c. 2000, 405.-406. lpp.

${ }_{21}$ Šulcs L. Profesora Konstantīna Čakstes zinātniskā darbība. Grām.: Andersons E., Siliṇš L. u. c. 2000, 397.-404. 1pp. 
pretlikumīgi tika iekḷauta Padomju Savienības sastāvā. ${ }^{22}$ K. Čakste to l̦oti pārdzīvoja, tomēr dzīve atlikušo gadu padomju okupācijā un gandrīz trīs gadus vācu okupācijā viṇa pretošanās garu nesalauza.

LCP ir vienīgā okupācijas laika kustība, kas vāca materiālus un informāciju par patieso situāciju un sabiedrības noskaņojumu nacistu okupētajā Latvijā, turklāt šìs ziņas no Latvijas diplomātiem Rietumos sasniedza arī dažādas Rietumu sabiedroto institūcijas. ${ }^{23}$ LCP atklāti vācu okupantiem izteica prasību nekavējoties atjaunot Latvijas Republikas faktisko suverenitāti. Tā bija vienīgā organizētā kustība, kas ir bijusi tiešos sakaros ar brīvās Latvijas sūtṇiem un tiem nodevusi savu memorandu par brīvības atjaunošanu. Viens no galvenajiem LCP izveidotajiem dokumentiem bija memorands par Latvijas Republikas neatkarības atjaunošanu. 1944. gadā LCP biedri Fēlikss Cielēns un Konstantīns Čakste izstrādāja memorandu - dokumentu ar pamatnostādnēm - prasību nekavējoties atjaunot Latvijas Republikas faktisko neatkarību, atjaunot Latvijas armiju, lai cīnītos pret draudošo padomju okupāciju. Neskatoties uz iespējamām vācu okupācijas iestāžu represijām, dokumentu parakstīja 189 (avotos ir pretrunīgi dati par parakstǐšanas datumu un parakstītāju skaitu) ${ }^{24}$ Latvijas politiķi, zinātnes un kultūras pārstāvji: Pauls Kalniņš, Kārlis Pauluks, Jāzeps Rancāns, Teodors Grīnbergs, Pēteris Juraševskis, Voldemārs Zāmuēls, Jānis Goldmanis, Kārlis Kundzin̦š, Pauls Kundziņš, Arveds Švābe, Kārlis Skalbe, Zinaīda Lazda, Ādolfs Erss, Elza Stērste, Mārtiņš Peniķis, Mārtiṇš Vācietis, Jānis Kurelis, Jānis Endzelīns, Jāzeps Vītols, Pēteris Mantnieks, Jānis Muncis u. c. Dokuments tika pārtulkots angḷ valodā, un Leonīds Siliņš to nogādāja Zviedrijā, kur tālāk to pārsūtīja sūtṇiem Kārlim Zariṇam Londonā un Alfrēdam Bīlmanim Vašingtonā, lai iesniegtu Rietumu valdībām. Dokumentā bija pausta viennozīmīga nostāja pret abām okupācijas varām. ${ }^{25}$ Tā tekstu pārfotografēja, pārtulkoja angḷu valodā, un dokumenta foto un mašinnraksta kopijas L. Siliņš slepeni pārveda pārī jūrai uz Zviedriju. ${ }^{26}$ LCP darbības pamatmērķis bija demokrātiskas suverēnas valsts atjaunošana ar ASV, Lielbritānijas un Zviedrijas atbalstu, kā arī Baltijas valstu konfederācijas vīzija nākotnē. Tika nodibināti kontakti ar līdzīgi orientētām organizācijām kaimiṇvalstīs - Lietuvas Atbrīvošanas padomi un Igaunijas Pretošanās kustību. ${ }^{27} \mathrm{LCP}$ dalībnieki domāja par valsts neatkarības un Satversmes atjaunošanu un nesadarbojās ar vācu iecelto pašpārvaldi Oskaru Dankeru, Mārtiṇu Prīmani, Rūdolfu Bangerski. Jānis Čakste vadīja Tautas

${ }^{22}$ Andersons E. Latvijas Centrālā Padome - LCP. Grām.: Andersons E., Siliṇš L. u. c. 2000, 13.-18. lpp.

${ }^{23}$ Neiburgs U. Draudu un cerību lokā. Latvijas pretošanās kustība un Rietumu sabiedrotie (1941-1945). Rìga: Mansards, 2017, 115. lpp.

${ }^{24}$ Ibid., 268.-269. lpp.

25 Andersons E., Siliņš L. u. c. 2000, 72. lpp.

26 Ibid., 70. lpp.

${ }_{27}$ Pēdējo vadija profesors Jiri Uluotss, par to raksta Jāns Kross savā jaunākajā, ar Baltijas asamblejas balvu apbalvotajā romānā "Lidojums uz vietas". LCP uzsvēra, ka Latvijas (un pārējo Baltijas valstu) inkorporācija Padomju Savienībā 1940. gadā ir bijusi starptautiski nelikumīga un ka tikpat nelikumīga ir nacistu radītā Ostlandes pārvaldes sistēma, kas nav izveidota ne saskaṇā ar starptautisko tiesību principiem, ne Hāgas konvencijām, ne Latvijas Republikas likumiem. LCP kategoriski nostājās pret Latvijas iedzīvotāju nelikumīgu mobilizēšanu Hitlera vācu armijā, ko okupanti viltīgi nosauca par brīvprātīgo ieroču SS leǵionu. Stradiņš J. Latvijas pamatā liktas demokrātiskas vērtības. Ievadruna Latvijas Zinātṇu akadēmijas pilnsapulcē 2002. gada 2. maijā. Jurista Vārds, 03.05.2002., Nr. 66 (2641). 
padomi, kas proklamēja neatkarīgo Latviju. ${ }^{28}$ 1944. gada 8. septembrī Rīgā bīskapa Rancāna dzīvoklī notika pēdējā LCP sēde Latvijā, kurā piedalījās generālis Tepfers, advokāts Breikšs, bīskaps Jāzeps Rancāns, Dr. Pauls Kalniņš, senators Mintauts Čakste un vēl dažas personas. Šajā sēdē Dr. Pauls Kalniṇš kā Valsts prezidenta vietas izpildītājs un Saeimas priekšsēdētājs parakstīja Deklarāciju par Latvijas valsts atjaunošanu. ${ }^{29}$ Nacionālās pretošanās kustības darbība okupācijas periodā kopumā un tai skaitā Padomes aktivitātes stiprināja Latvijas tautas negrozāmo valstsgribu (nostiprinot valstiskuma parlamentāro un demokrātisko tradīciju) un radīja pamatu pārliecībai, ka Latvija nekad nav beigusi pastāvēt un tās neatkarība tiks atjaunota ${ }^{30}$ LCP arī palīdzēja kara bēgḷiem tikt pāri Baltijas jūrai un nokḷūt Zviedrijā. ${ }^{31}$

Profesora K. Čakstes darbība nācijas interesēs savu lielāko spriegumu sasniedza tieši pretešķībām un galējībām pārpilnā okupācijas laikā. Jo patiesi derīgi nacionāli darboties mēs varam tikai uz savas zemes, kur tūkstošu citu dzīve līdzās mums ik brīdi dod jaunus pamudinājumus un impulsus mūsu darbam. ${ }^{32}$ Domājot par mūsdienu politikas norisēm, jānorāda uz riskiem K. Čakstes vārdu izmantot tikai sava politiskās elites pārstāvja paštēla spodrināšanā publiskajā telpā, demonstrējot nepietiekamu izpratni un iedziļināšanos Latvijas pretošanās kustības vēsturē kopumā. ${ }^{33}$ Iestājoties par Latvijas demokrātiskās valdības atjaunošanu, kā likumīgs Valsts prezidenta aizstājējs J. Rancāna dzīvoklī P. Kalniṇš parakstīja dokumentu, kas pilnvaroja prof. Konstantīnu Čaksti 1944. gadā uzṇemties valdības sastādī̌̌anu piemērotā laikā un vietā. Pēc tam vēl vairākas reizes notika tikšanās LCP apspriedēs pie generāļa Vernera Tepfera, un tad "pēkšņi 1944. gada septembrī mūs izšḳira uz visiem laikiem”. ${ }^{34}$ 1944. gada 8. septembra Deklarācija par Latvijas valsts atjaunošanu, kuru saskaṇā ar Satversmes 44. pantu Latvijas Republikas okupācijas apstākḷlos izdevis Valsts prezidenta vietas izpildītājs un Saeimas priekšsēdētājs Pauls Kalniņš, uzskatāma par spēkā esošu konstitucionāla ranga aktu. Deklarācija uzskatāma par vienu no Latvijas rakstītās konstitūcijas sastāvdaḷām. ${ }^{35}$ Vēsturnieks Uldis Neiburgs nav izslēdzis, ka drošības nolūkos tikuši sagatavoti

${ }^{28}$ Konstantīns Čakste 1944. gadā cerēja uzṇemties atjaunotās neatkarīgās Latvijas valdību kā tās Ministru prezidents. Simboliski. Viņi cerēja, ka situācija Latvijā 1944./1945. gadā varētu veidoties līdzīga tai, kāda bija bijusi neatkarības izcīnīšanas laikā 1918.-1919. gadā. K. Čakstem bija samērā plašs atbalsts tieši akadēmiskajās aprindās - Latvijas Universitātē un Jelgavas Lauksaimniecības akadēmijā. Stradinšs J. 2002.

29 Andersons E., Siliņš L. u. c. 2000, 82.-83. lpp.

30 Jundzis T., Turčinskis Z. Pretošanās padomju un nacistiskajam režīmam Latvijā 1940.-1985. gadā. Grām.: Latvija un latvieši. Akadēmiskie raksti. II sēj. Rịga: Latvijas Zinātṇu akadēmija, 2017, 639.-640. lpp. Sk. arī: Pleps J. Latvijas Centrālās padomes 8. septembra deklarācijas valststiesiskā nozīme. Jurista Vārds, 04.09.2018., Nr. 36 (1042), 13. lpp.

31 Saskaņā ar oficiāli reg̣istrētiem datiem līdz Otrā pasaules kara beigām Zviedrijā ieradušies 4559 latviešu bēg̣̣i. 2541 bēglis tur bija nonācis ar LCP organizēto bēgḷu laivu akciju rezultātā. Jo vairāk bēgḷu ieradās, jo grūtāk bija turēt slepenībā visu evakuācijas darbību. Par to īpaši rūpējās zviedru sarkanā prese. LCP panāca arī leǵionāru atbrīvošanu no gūsta. LCP protesti, vēstules, memorandi emigrācijā veido 51 vienību: Andersons E. Latvijas Centrālā Padome - LCP. Grām.: Andersons E., Siliņš L. u. c. 2000, 214. lpp.

32 Neimanis V. Profesoru Konstantīnu Čaksti pieminot. Grām.: Andersons E., Silinš̌ L. u. c. 2000, 408. lpp.

33 Neiburgs U. 2017, 93.-94. lpp.

34 Rancāns J. Likumīgais Latvijas sargs. Bijušā Saeimas prezidenta Dr. Paula Kalniṇa piemiṇai viṇa 80. dzimšanas dienā. Bīskaps Jāzeps Rancāns. Rakstu izlase. Prof. Dr. H. Tichovska redakcijā. Toronto: Astras Apgāds, 1977, 122. lpp.

35 Plašāk sk.: Pleps J. 2018, 13. lpp. 
divi alternatīi rīkojumi par valdības veidošanu, to attiecīgi uzticot abiem brāliiem. ${ }^{36}$ Atrodoties apcietinājumā, izpaudās K. Čakstes morālais spēks un gara

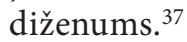

Universitātes mācībspēki sagatavoja galvojuma tekstu un lūgumu atbrīvot Konstantīnu Čaksti. Par viṇa atbrīvošanu iestājās Zenta Mauriņa, Jāzeps Rancāns, Pauls Kḷaviņš, Edgars Dunsdorfs, Lotārs Šulcs, pat piesardzīgais Rūdolfs Bangerskis u. c. Tomēr panāca tikai to, ka atḷauj nodot K. Čakstem grāmatas un dzīvesbiedres drīkstēja apmeklēt savus vīrus cietumā. ${ }^{38} \mathrm{~K}$. Čakste izglāba ebreju jaunekli Leonu Panci no gāzes kameras, noslēpjot to barakā un l̦aujot pievienoties ieslodzìto grupai darbā ārpus nometnes. Viņam pieškirirts tituls "Taisnīgais starp tautām”. 39

Atmin̄ās par sava vīra Konstantīna īso, bet darbīgo mūžu Anastasija Čakste raksta: "Viṇa spēka avots bija ticība sev, dzīvei un mūžìbai. Viṇā nekad neizsīka radīšanas, dzīves veidošanas prieks. Konstantīns cienīja pienākumu un darbu, juta dzil̦u godbijību pret likumu, kas stāv pāri cilvēkiem un viņu varai, un bija gatavs nest upurus, ja pienākums to prasa. Viṇa radošā ideja iecerēja nākotni skaistāku, pilnīgāku, daudzkrāsaināku. Konstantīnam piemita izsmalcināta orientēšanās spēja ne tik vien zinātnē, bet arī rakstniecībā un mākslā. Viṇš labprāt dalījās savos uzskatos un dāvāja savu dzīves ziṇu citiem. Aizrāva studentus ar savu dvēseles kvēli un darba prieku. Konstantīns vienmēr bija patiess un laipns, pašsavaldīgs, pacietīgs, kā arī labvēlīgs pret citiem cilvēkiem. Viṇa garam bija stipri spārni, tie cilājās brīvi, spēcīgi, cēli un viegli." ${ }^{40}$ Korporācijas biedrs Arvīds Jaunarājs atceras: "Kad Latvijā valdīja okupācijas vara, prāvu starpbrīdi pie manis bija iegriezies Konstantīns Čakste. Kad mēs izteicām pesimistiskas domas, Konstantīns Čakste mums atbildēja: "Es gan esmu pilnīgi pārliecināts, ka Latvija būs atkal, bet tikai es nezinu, vai mēs to piedzīvosim."'41

K. Čakstem bija jāpiedzīvo arī liela vilšanās - profesora Vasilija Sinaiska novēršanās. Viṇš no Štuthovas nometnes rakstīja Arvīdam Jaunarājam, ka Prāgā vajagot atrasties profesoram Vasilijam Sinaiskim, un lūdza vinu uzmeklēt, nodot sveicienus un lūgt atrakstīt vēstuli. A. Jaunarājs sameklēja Sinaiski un nodeva vēstuli: "Liels pārsteigums man bija, kad otrā un pēdējā vēstulē, kas rakstīta 1945. gada 7. janvārī, Konstantīns Čakste man raksta, ka no profesora Sinaiska vēstuli neesot saṇēmis, un arì viṇš no savas puses neesot Sinaiskim rakstījis, jo varbūt, pēdējam esot nepatīkami no turienes vēstules saṇemt. Un rūgtākais teikums visā vēstulē ir tas, kur viņš piemin, kas viņam rakstījuši .., un tad saka: "Mani pārējie draugi mani ir aizmirsuši vai arī rakstīs normālos laikos"." 42 Kā savās atmiṇās par sarunu

36 Pleps J. 2018, 12. lpp. Plašāk sk.: Neiburgs U. Latvijas Republikas Saeimas priekšsēža Paula Kalniņa 1944. gada 8. septembra deklarācija par Latvijas valsts atjaunošanu un valdības izveidošanu. Latvijas Vēstures Institūta Žurnāls, 2014, Nr. 3 (92), 134.-136. lpp.

${ }^{37}$ Profesora klātbūtnē gestapovieši pratināja viṇa studentus, lai atklāj, kurš ir LCP vadītājs. Viens jauneklis, students Jānis Arvīds Atvars, neizturēja sadistisko spīdzināšanu un eksekūcijas laikā nomira. Lai paglābtu citus no fiziskām mokām, viṇš atzinās un lūdza varmākas pārtraukt bezjēdzīgi sist studentus, kuri neko nav noziegušies. Andersons E., Siliņš L. u. c. 2000, 91. lpp.

38 Auziñš A. 2004, 70.-71. lpp.

${ }^{39}$ Ibid., 73. lpp. Nomocītie ieslodzītie centās piemānīt l̦auno likteni - mācījušies angḷu valodu, dziedājuši, spēlējuši šahu pēc redzes atmiņas.

${ }^{40}$ Ibid., 89. lpp.

${ }^{41}$ Jaunarājs A. Atmiṇas par vecbiedru prof. Konstantīnu Čaksti. Grām.: Andersons E., Siliṇš L. u. c. 2000, 395. lpp.

42 Ibid., 395.-396. lpp. 
ar profesora V. Sinaiska meitu N. Sinaisku dalās Tallinas Universitātes profesors Pēters Jervelaids (Peeter Järvelaid), V. Sinaiskis līdz pat sava mūža pēdējām dienām nevarēja sev piedot, ka nav atsaucies Konstantīna lūgumam. ${ }^{43}$

Konstantīna kolēgis docents Benno Ābers atzina: "Savā politiskajā ticības apliecībā un Rietumu orientācijā Konstantīns Čakste nepārprotami bija latvju tautas vairākuma gribas un noskaṇojuma pārstāvis un dedzīgs, nesavtīgs cīnītājs šo nacionālo ieceru îstenošanai." ${ }^{4}$ B. Ābers rakstīja: "Tā vēl pirms Otrā pasaules kara beigām traǵiskos apstākḷos aizgāja bojā vīrs, kura lielākais sapnis bija uz kara drupām celt jaunu patstāvīgu Latvijas valsti, kur valdìtu tauta demokrātiskā, tiesiskā iekārtā. Vīrs, kura dzimtas saknes norādīja uz izcilu vietu latvju nācijā. Vīrs, ko lielāko latviešu politisko partiju līderi bija izraudzījuši par savu vadìtāju un nākamo Latvijas Ministru prezidentu. Konstantīns Čakste arī nešaubīgi ticēja, ka latvju tautai neatkarību atgūt palīdzēs Rietumu sabiedrotie. Tāpēc arī Latvijas Centrālā padome K. Čakstes vadībā centās jau kara laikā nodrošināt sadarbību ar Rietumu nācijām, uzṇemoties vislielāko risku vācu okupācijas apstākḷos." ${ }^{45}$

\section{Vienreizïba ir stūrakmens! Post scriptum}

Tiesību teorijas un vēstures zinātṇu sekcijas sēde šogad veltīta profesora Romāna Apsī̌̌a nozīmīgajai dzìves jubilejai. Viṇš - viens no 1990. gada deklarācijas "Par Latvijas Republikas neatkarības atjaunošanu” autoriem (îpašu uzmanību veltot tās preambulai), šì gada februārī svinēja astoņdesmito dzimšanas dienu. Enciklopēdists, 5. un 6. Saeimas deputāts, mācībspēks, četrdesmit gadus bijis Juridiskās fakultātes docētājs, tieslietu ministrs, pirmā sastāva Satversmes tiesas tiesnesis, pirmais tiesībsargs. ${ }^{46}$ Savā zinātniskajā darbībā R. Apsītis sniedzis būtisku ieguldījumu Latvijas tiesību vēstures izpētē un juridiskās terminologijas pilnveidošanā. Tiesību vēsturnieka zināšanas l̦āvušas precīzi dokumentēt nepieciešamos faktus, lai pamatotu Latvijas Republikas nepārtrauktības doktrīnu, uz kuru balstās mūsdienu Latvijas Republikas tiesiskā sistēma.

Egils Levits uzsvēris, kā kalpot Latvijai: "To es varu darīt kā zinātnieks, to es varu darìt kā tiesnesis, to es varu darìt kā sabiedriskais darbinieks. Bet motivācija vienmēr ir - Latvijas valsts nostiprināšana un uzlabošana." ${ }^{47}$ Cilvēcība, gimeniskums, nerimstoša sabiedriskā darbība, valstsvīra stāja vieno personības un sasien laikus kopējos pavedienos. Romāna Apsǐša pašreizējo interešu lokā ir viṇa patlaban pilnveidojamā disertācija trīs daḷās, kas rakstīta ar sirdi un dvēseli - "Koris "Daile". Vēsturisks apskats (1951-1998)". Tā ir kora dzīves hronika, vienā no

${ }^{43}$ No profesora P. Jervelaida stāstījuma 2019. gada 28. februārī. Personiskā arhīva materiāli.

44 Auziņš A. 2004, 90. lpp.

45 Andersons E., Silin̦š L. u. c. 2000, 98. lpp.

${ }^{46}$ Plašāk sk.: Apse D. Personība, pēctecība un Latvijas tiesiskā doma. Likums un Tiesības, 2009, 11. sēj., Nr. 5, 155.-159. lpp.

47 Vismaz divas partijas kā nākamo prezidentu vēlētos redzēt Egilu Levitu. Pieejams: https://www. apollo.lv/6522773/vismaz-divas-partijas-ka-nakamo-prezidentu-veletos-redzet-egilu-levitu [aplūkots 25.02.2019.]. 
nodaḷām izskan - vienreizība ir stūrakmens! ${ }^{48}$ Tieši tas pēctecīgi vieno personības, viņu paveikto Latvijas valsts kontinuitīvai un mērḳtiecīgai attīstībai.

\section{Kopsavilkums}

1. Konstantīna Čakstes dzīves gaitas apliecina viṇa uzticību nezūdošām garīgām vērtībām. Viṇa paveiktais kalpo tautai un nezudīs no tās pieminas. Konstantīns Čakste cēla stipru tiltu starp diviem laiku lokiem - Latvijas valsts atjaunošanas mēginājumu Otrā pasaules kara beigās - "trešo fronti" ar Trešo atmodu un 1990. gada deklarāciju "Par Latvijas Republikas neatkarības atjaunošanu", ar kuru 1990. gada 4. maijā tika atjaunota Satversmes sapulces 1922. gada 15. februārī pieṇemtā Latvijas Republikas Satversme. Šì deklarācija 1940. gada 17. jūnija PSRS militāro agresiju pasludināja par starptautisku noziegumu un atjaunoja Latvijas Republikas suverenitāti.

2. K. Čakstes zinātniskā devuma vērtējums salīdzinājumā ar mūsdienām nav bijis apjomīgs. To var skaidrot ar vēsturisko fonu, profesora aktīvo sabiedriski politisko darbību, pāragro un traǵisko bojāeju.

3. Konstantīnu Čaksti paturēsim neizdzēšamā atmiṇā. Viṇa cēlos darbus atminēsimies ar patiesu cieņu un atzinību. Visdziḷākā pateicība Konstantīnam Čakstem kā moceklim un priekšlaicīgam upurim - dzīvības ziedotājam par demokrātisku tiesisku valsti un Latvijas tautas brīvību.

4. Pateicība visām tām personībām, kas kopā ar citiem lika juridiskos pamatus Latvijas valsts atjaunošanai un ar savu lielo ticíbu Latvijas valstij un latviešu nācijai turpināja Latviju - attīstīja valsti kontinuitīvi un mērḳtiecīgi, piedaloties tās tiesiskās sistēmas pilnveidošanā.

\footnotetext{
${ }^{48}$ No sarunas ar Romānu Apsīti 13.02.2019. un 24.02.2019. Personiskā arhīva materiāli. Kora dzīves hronika veidota atškiirīgi no muzikologa Artura Vernera 1981. gadā rakstītā par kordiriǵgentiem Imantu un Gido Kokariem. Kā sacīja nu jau aizsaulē aizgājušais korists Zigurds Briedis: tas tik ir koris "Dilaila" (domāts koris “Daile”)! Darbs veidots kā daudzšḳautņaina mozaīka, ko darinājuši gan kora dalībnieki ar savām atmin̄ām, gan kora vairākkārtējais prezidents Romāns Apsītis. Darbam ir vairāk nekā 200 A4 lapas, tajā izmantotas paša autora un korista Z. Brieža dzejā paustās atmiņas par pieredzēto kora dzīvē, Selgas Palu (prec. Kaṇepes), Zigrīdas Bīrītes atmiṇas par “Dailes” laiku LU paspārnē, par kora darbības pirmsākumiem, par braucienu uz Karpatiem, Ilgvara Matroža klātbūtnes laiku korī, par “Dziesmu karu” karoga vairākkārtējo iegūšanu pēc 1955. gada (nodaḷā “"Vienreizība atgriezās” ar "Lauztajām priedēm"”).
} 